\title{
Urea Deep Placement in Rice as an Option for Increasing Nitrogen Use Efficiency
}

\author{
Amina Khatun1", Hasina Sultana1, M. A. U. Zaman1, Shila Pramanik¹, M. A. Rahman² \\ ${ }^{1}$ Rice Farming Systems Division, Bangladesh Rice Research Institute, Gazipur, Bangladesh \\ ${ }^{2}$ Farm Machinery and Post Harvest Technology Division, Bangladesh Rice Research Institute, Gazipur, \\ Bangladesh \\ Email:
}

Received 2 April 2015; accepted 17 April 2015; published 22 April 2015

Copyright (C) 2015 by authors and OALib.

This work is licensed under the Creative Commons Attribution International License (CC BY). http://creativecommons.org/licenses/by/4.0/

(c) (i) Open Access

\section{Abstract}

Prilled urea applicator is a nitrogen saving technology. Aiming to find out the efficiency of BRRI prilled urea applicator, a field experiment was conducted during boro season of 2013-2014 at the Bangladesh Rice Research Institute (BRRI) experimental farm, Gazipur and at farmer's field of Dhirasshram village under Gazipur Sadar Upazilla, Gazipur, Bangladesh. Four treatments viz. 1) hand broadcasting of prilled urea as per BRRI recommendation $\left.\left(\mathrm{T}_{1}\right), 2\right)$ prilled urea application by applicator $\left(70 \%\right.$ of the BRRI recommended dose) $\left.\left(\mathrm{T}_{2}\right), 3\right)$ hand broadcasting of prilled urea $(70 \%$ of the BRRI recommended dose) $\left(\mathrm{T}_{3}\right)$ and 4) $\mathrm{N}$-control $\left(\mathrm{T}_{4}\right)$ were evaluated in the study. The $\mathrm{T}_{2}$ treatment gave the highest grain yield of $6.96 \mathrm{t} \cdot \mathrm{ha}^{-1}$ and $7.20 \mathrm{t} \cdot \mathrm{ha}^{-1}$ at BRRI farm and Dhirasshram village, respectively, followed by those of $T_{1}$ treatment. The highest agronomic use efficiency was obtained from $\mathrm{T}_{2}$ treatment in both the locations. Similar scenario for apparent recovery efficiency, utilization efficiency and partial factor productivity was also observed in $\mathbf{T}_{2}$ treatment. Moreover, about thirty percent prilled urea was saved due to deep placement of urea by applicator in boro season.

\section{Keywords}

Applicator, N Fertilizer, Rice (Oryza sativa L.), N Use Efficiency

Subject Areas: Agricultural Science

\section{Introduction}

Bangladesh is one of the largest deltas of the world with a total area of $147,570 \mathrm{sq} . \mathrm{km}$. With a unique communal harmony, Bangladesh has a population of about 151 million making it one of the densely populated countries

${ }^{*}$ Corresponding author.

How to cite this paper: Khatun, A., Sultana, H., Zaman, M.A.U., Pramanik, S. and Rahman, M.A. (2015) Urea Deep Placement in Rice as an Option for Increasing Nitrogen Use Efficiency. Open Access Library Journal, 2: e1480.

http://dx.doi.org/10.4236/oalib.1101480 
of the world. Demand for food is proportion to the population growth [1]. Agriculture, of course, is the main source of income and employment in rural areas; indeed, in poorer countries it is often the principal employer in the entire economy. Cereal crops, predominantly rice, are the mainstay of Bangladesh's agriculture. About $90 \%$ of rice is produced and consumed in Asia. By the year 2025, it is estimated that it will be necessary to produce about $60 \%$ more rice than what is currently produced to meet the food needs of a growing world population [2]. Scientists are trying to develop new production technologies and the people related to food production try to increase production to feed the ever increased populations. Historically, rice cultivation is a labor-intensive task that could not be accomplished easily. Labor cost accounts the biggest input cost for rice production [3]. In Bangladesh, about $90 \%$ of labor has been engaged in rice cultivation. But, the number of agriculture labor is decreasing day by day. Labor scarcity being the major reason for the decline in rice production and to overcome this, farm mechanization has been considered as an important remedial measure.

Agricultural machines have replaced human force in many rice cultivation practices such as land preparation, transplanting, harvest, and post-harvest process in many developed countries. Though land preparation, weeding and threshing in many cases are performing mechanically but nitrogen fertilizer application is still done traditionally in Bangladesh and about 156 man-days per hectare are required for producing rice [1].

Nitrogen is one of the most yield-limiting nutrients in rice production around the world [4], especially in tropical Asian soils and almost every farmer has to apply the costly $\mathrm{N}$ fertilizer to get a desirable yield of rice [5]. Judicious and proper use of fertilizers can markedly increase the yield and improve the quality of rice [6]. The efficient use of $\mathrm{N}$ fertilizer is recognized as an important factor for rice cultivation, but it has always been a problem to raise the $\mathrm{N}$ utilization rate of the rice plants and to increase the efficiency of absorbed $\mathrm{N}$ for grain production irrespective of the amounts of $\mathrm{N}$ being applied. Low $\mathrm{N}$ fertilizer use or recovery efficiency remains a problem in rice production in Asia. The low efficiency of $\mathrm{N}$ fertilizers is mainly due to loss of applied $\mathrm{N}$ through leaching, volatilization, surface runoff, and denitrification in the soil-flood water system [7].

Prilled urea is the most popular fertilizer material used for rice production in Asia. Over the last few decades, an unusually large number of deep placement applicators have been developed for prilled urea in Japan, China and at IRRI [8]. Fertilizer use efficiencies in upland farming have been reported to be $50 \%$ to $60 \%$ [9] when those obtained under wetland farming conditions are generally 30\% - 50\% [10]. [8] reported that a placement depth of $4-5 \mathrm{~cm}$ was more than adequate to minimize $\mathrm{N}$ transfer to flood water with prilled urea. It has been generally believed that placement at greater depth is necessary for improving fertilizer use efficiencies in wetland cultivation and hence 5 - $20 \mathrm{~cm}$ placement depths have often been recommended. Deep placement of urea fertilizer is probably the most effective application method in reducing nitrogen loss except in soils with high percolation rates. Deep-point placement (5 - $10 \mathrm{~cm}$ depth) in anaerobic soil layer 1) limits the concentration of $\mathrm{N}$ in flood water and in the surface oxidized layer; 2) decreases $\mathrm{N}$ losses through runoff, ammonia volatilization, and denitrification [11].

In Bangladesh, surface-split application of prilled area with fixed rates at specific growth stages is currently recommended. Split application for increasing nitrogen use efficiency is often not practical in lowland rice due to adverse soil-water situations. Rather it enhances $\mathrm{N}$ losses from oxidized soil zone [11]. On the other hand, in deep placement of prilled urea, the entire required amount of $\mathrm{N}$ has to be applied in reduced soil layer once single application when the water regime is favorable. So, the $\mathrm{N}$ fertilizer loss reduced significantly except in very coarse-textured soils. Under these circumstances, the present study was designed 1) to find out the amount of saved urea using applicator, 2) to determine NUE of different applied methods of $\mathrm{N}$ application and 3) to compare the yield and yield contributing characters under varying methods of $\mathrm{N}$ application.

\section{Materials and Methods}

The field experiments were conducted during boro season (November-April) of 2013-2014, at the experimental farm of the Bangladesh Rice Research Institute, Gazipur and at farmer's field of Dhirasshram village under Gazipur Sadar Upazila, Gazipur, Bangladesh, located at $23^{\circ} 59^{\prime} \mathrm{N}$ latitude, $90^{\circ} 24^{\prime} \mathrm{E}$ longitude. The soil of the experimental fields was Chhiata clay loam, a member of the fine, hyperthermic Vertic Endoaquept [5]. The site is about $35 \mathrm{~m}$ above the mean sea level and has a subtropical climate, which is strongly influenced by the southwestern monsoon. It belongs to Agro-Ecological Zone (AEZ) number 28 known as Madhupur Tract. The average annual rainfall is $2000 \mathrm{~mm}$ with more than $80 \%$ of it occurring from mid-June to the end of September. Mean temperature is lowest $\left(15^{\circ} \mathrm{C}\right)$ in January and highest $\left(30^{\circ} \mathrm{C}\right)$ in May. 
A short duration high yielding boro rice variety, BRRI dhan28 (growth duration 145 days) were grown under fully irrigated conditions in both the locations. The crop was transplatned in $2^{\text {nd }}$ week of January with $42-45$ day old seedlings and harvested in May. Two/three rice seedlings were transplanted maintaining $20 \times 20 \mathrm{~cm}$ spacing. The seed rate for rice was $30 \mathrm{~kg} \cdot \mathrm{ha}^{-1}$. The experiments were conducted in a randomized complete block design with three replications. Unit plot size was $(6 \mathrm{~m} \times 8 \mathrm{~m})$ in BRRI farm and $(10 \mathrm{~m} \times 8 \mathrm{~m})$ in Dhirasshram village. All plots were surrounded by soil levees $30 \mathrm{~cm}$ high maintaining $50 \mathrm{~cm}$ drain between the plots to avoid $\mathrm{N}$ contamination and easy movement of the applicator between plots.

Phosphorus, K, S \& Zn were applied as triple super phosphate (TSP), muriate of potash (MP), gypsum and zinc sulphate $\left(\mathrm{ZnSO}_{4}\right)$, respectively, during final land preparation as per soil test basis (STB). Four treatments i.e. 1) hand broadcasting of prilled urea as per BRRI recommendation (one-third of $\mathrm{N}$ was applied at initiation of tillering) (IT) + one-third at active tillering stage (AT) + one-third at panicle initiation (PI) ( $\left.\mathrm{T}_{1}\right)$, 2) prilled urea application by applicator (application of $70 \%$ of the BRRI recommended dose) $\left(\mathrm{T}_{2}\right)$, 3) hand broadcasting of prilled urea (application of $70 \%$ of the BRRI recommended dose) $\left(\mathrm{T}_{3}\right)$ and 4$) \mathrm{N}$-control $\left(\mathrm{T}_{4}\right)$ were evaluated in the study. In $T_{2}$ treatment, instead of splitting, the entire amount of prilled urea was applied in $4-5 \mathrm{~cm}$ depth in reduced soil layer using applicator at immediate after transplanting (2 days after). The recommended dose of urea was $300 \mathrm{~kg} \cdot \mathrm{ha}^{-1}$. Other fertilizers were applied @ 90-125-55-6 kg $\mathrm{ha}^{-1}$ of TSP, MP, gypsum, $\mathrm{ZnSO}_{4}$, respectively, during final land preparation and were thoroughly incorporated into the soil.

Tiller numbers were counted in $1 \mathrm{~m}$ rows at four places in each plot at every 15 days interval from transplanting to maturity. The 16 hills were selected at random in each plot just before harvesting to estimate plant height and number of tillers. The panicle numbers were determined from 16 hill sample at harvesting. The panicles from the 16 hills were threshed. The grains and sterile spikelets were separated by a seed sorter. After separation, the grains and sterile spikelets were counted by an automatic counter. Then the grain number panicle ${ }^{-1}$, weight of 1000 grains were measured at $14 \%$ moisture and sterility (\%) were calculated by following standard procedures as described by [12]. Straw yield was recorded from 16-hill sample at maturity and adjusted to oven dry basis.

Rice plants from $5 \mathrm{~m}^{2}$ area of the middle of each plot were harvested at ground level and threshed. The grains were dried in sunlight and winnowed before weighing and the grain yield was adjusted to $14 \%$ moisture content and was converted into t.ha ${ }^{-1}$, using the following formula:

$$
\text { Adjusted weight }=\frac{W \times(100-M 1)}{(100-M 2)} \times 100
$$

where, $W$ is the fresh weight of the grains and $M 1$ and $M 2$ are the fresh and adjusted moisture percents of the grain, respectively.

Harvest index $(H I)$ was computed by dividing the grain yield by the total dry matter (grain yield + straw yield) and was expressed as percentage as follows:

$$
H I=\left(\frac{\text { Grain yield }}{\text { Grain yield }+ \text { Straw yield }}\right) \times 100 \text {. }
$$

Sterility was computed by dividing the number of unfilled spikelets by the total number of spikelets (filled grains + unfilled spikelets) and was expressed as percentage as follows:

$$
\text { Sterility }(\%)=\left(\frac{\text { Unfilled spikelets }}{\text { Unfilled spikelets + filled grains }}\right) \times 100 \text {. }
$$

Nitrogen use efficiencies were calculated using the following formulas [13]:

Agronomic efficiency $(A E)$. It was expressed as difference in grain yield between fertilized and unfertilized plot divided by the quantity of nutrient applied. It was expressed as $\mathrm{kg} \cdot \mathrm{kg}^{-1}$.

$$
A E=\frac{\left(G_{f}-G_{u}\right)}{N_{a}}
$$

where $G_{f}$ was the grain yield of the fertilized plot $(\mathrm{kg}), G_{u}$ was the grain yield of the unfertilized plot $(\mathrm{kg})$, and $N_{a}$ was the quantity of $\mathrm{N}$ applied (kg).

Physiological use efficiency (PE). The physiological efficiency was the difference in biological (grain + straw) 
yield between fertilized and unfertilized plots over difference in nutrient uptake between fertilized and unfertilized plots. It was expressed as $\mathrm{kg} \cdot \mathrm{kg}^{-1}$.

$$
P E=\frac{\left(Y_{f}-Y_{u}\right)}{\left(N_{t f}-N_{t u}\right)}
$$

where $Y_{f}$ was the total biological yield (grain plus straw) of the fertilized plot (kg), $Y_{u}$ was the total biological yield of the unfertilized plot $(\mathrm{kg}), N_{t f}$ was the nutrient accumulation of the fertilized plot $(\mathrm{kg})$, and $N_{t u}$ was the nutrient accumulation of the unfertilized plot $(\mathrm{kg})$.

Agrophysiological efficiency (APE). The difference in grain yield between fertilized and unfertilized plots divided by the difference in nutrient uptake in them was known as Agrophysiological efficiency (APE).

$$
A P E=\frac{\left(G_{f}-G_{u}\right)}{\left(N_{t f}-N_{t u}\right)}
$$

where $G_{f}$ was the grain yield of the fertilized plot $(\mathrm{kg}), \mathrm{G}_{\mathrm{u}}$ was the grain yield of the unfertilized plot $(\mathrm{kg}), N_{t f}$ was the $\mathrm{N}$ accumulation by straw and grains in the fertilized plot $(\mathrm{kg}), N_{t u}$ was the $\mathrm{N}$ accumulation by straw and grains in the unfertilized plot $(\mathrm{kg})$. The unit of agrophysiological efficiency was $\mathrm{kg} \cdot \mathrm{kg}^{-1}$.

Apparent recovery efficiency (ARE). It stated that the percentage of the applied nutrient that was apparently absorbed the crop.

$$
\operatorname{ARE}=\frac{\left(N_{f}-N_{u}\right) \times 100}{N_{a}}
$$

where $N_{f}$ was the $\mathrm{N}$ accumulation by the total biological yield (grain plus straw) in the fertilized plot (kg), $N_{u}$ was the $\mathrm{N}$ accumulation by the total biological yield (grain plus straw) in the unfertilized plot (kg), and $N_{a}$ was the quantity of $\mathrm{N}$ applied $(\mathrm{kg})$.

Utilization efficiency (UE). The product of physiological efficiency and apparent recovery efficiency was known as utilization efficiency (UE). Essentially, the $U E$ was dimensionless.

$$
U E=P E \times A R E
$$

Partial factor productivity (PFP). The grain yield per quantity of nutrient applied, was considered as partial factor productivity (PFP). It was also unitless.

$$
P F P=\frac{G_{f}}{N_{a}}
$$

where $G_{f}$ was the grain yield of the fertilized plot $(\mathrm{kg})$ and $N_{a}$ was the quantity of $\mathrm{N}$ applied $(\mathrm{kg})$.

Finally, data were analyzed through Crop Stat windows version 7.2. Analysis of variance (ANOVA) of the measured parameters was performed and the treatment means were compared using Least Significant Difference (LSD) at the $5 \%$ level of probability [14].

Economic study was calculated using Bangladeshi economic values. The cost of seed, labour, irrigation, fertilizer except urea and other cultural practices was same for all the treatments. The price of urea was TK. $20 \mathrm{~kg}^{-1}$ and the currency conversion factor used was 1 US $\$=80$ Bangladeshi Taka.

\section{Results and Discussion}

\subsection{Tillering Pattern}

Tiller production at different growth stages is presented in Table 1. At 15 days after transplanting (DAT), the tiller number per $\mathrm{m}^{2}$ varied from 58 to 81 irrespective of locations. At 30 DAT, tiller production was significantly higher at Dhirasshram village compared to that of BRRI farm for all the treatments. At BRRI farm, the treatment $T_{1}$ produced significantly higher number of tillers than other treatments. But at Dhirasshram village, the $T_{2}$ treatment produced the higher number of tillers followed by $T_{1}$ treatment. At $45 \mathrm{DAT}$, the $\mathrm{T}_{1}$ and $\mathrm{T}_{2}$ treatments showed statistically similar tiller productions both at BRRI farm and Dhirasshram village. The tiller number was significantly higher at Dheerasram village compared to that of BRRI farm in all the treatments. At 60 DAT, the $\mathrm{T}_{2}$ treatment produced higher number of tillers compared to all other treatments. The tiller production 
Table 1. Number of tillers of BRRI dhan28 under different nitrogen application methods during the growth cycle.

\begin{tabular}{|c|c|c|c|c|}
\hline \multirow{2}{*}{ Treatment } & \multicolumn{4}{|c|}{ Days after transplanting (DAT) } \\
\hline & $15 \mathrm{DAT}$ & $30 \mathrm{DAT}$ & 45 DAT & 60 DAT \\
\hline & \multicolumn{4}{|c|}{ Tiller $\mathrm{m}^{-2}$} \\
\hline \multicolumn{5}{|c|}{ BRRI farm } \\
\hline $\mathrm{T} 1$ & 71 & 185 & 349 & 363 \\
\hline $\mathrm{T} 2$ & 58 & 137 & 347 & 391 \\
\hline T3 & 67 & 127 & 311 & 337 \\
\hline $\mathrm{T} 4$ & 81 & 119 & 210 & 252 \\
\hline \multicolumn{5}{|c|}{ Dhirasshram village } \\
\hline $\mathrm{T} 1$ & 62 & 189 & 387 & 401 \\
\hline $\mathrm{T} 2$ & 66 & 192 & 401 & 437 \\
\hline $\mathrm{T} 3$ & 71 & 181 & 331 & 358 \\
\hline $\mathrm{T} 4$ & 79 & 155 & 280 & 302 \\
\hline CV (\%) & 5.2 & 4.9 & 6.0 & 4.0 \\
\hline F-values for $\mathrm{L}$ & NS & ${ }^{* *}(6.94)$ & ${ }^{* *}(17.19)$ & ${ }^{* *}(12.45)$ \\
\hline F-values for $\mathrm{T}$ & ${ }^{* *}(4.43)$ & ${ }^{* *}(9.81)$ & ${ }^{* *}(24.30)$ & ${ }^{* *}(17.60)$ \\
\hline F-values for $\mathrm{Lx} \mathrm{T}$ & ${ }^{* *}(6.27)$ & ${ }^{* *}(13.87)$ & NS & NS \\
\hline
\end{tabular}

${ }^{*},{ }^{* *}$, NS significant at the 0.05 and 0.01 probability levels and non-significant, respectively.

was higher at Dhirasshram compared to BRRI farm at 30, 45 and 60 DAT. Moreover, the $\mathrm{T}_{4}$ treatment gave the lowest number of tillers at 30, 45 and 60 DAT in both the locations.

\subsection{Grain Yield}

The interaction effect of location ( $\mathrm{L}$ ) and treatment $(\mathrm{T})$ was insignificant $(\mathrm{P}>0.05)$, but the individual effect of $\mathrm{L}$ and $\mathrm{T}$ was significant on grain yield (Table 2). The grain yield ranged from 3.22 to $6.96 \mathrm{t}^{\mathrm{h}} \mathrm{ha}^{-1}$ at BRRI farm and 4.37 to $7.20 \mathrm{t}^{\mathrm{h} \mathrm{ha}^{-1}}$ at Dhirasshram, respectively, irrespective of treatments. At BRRI farm, the maximum grain yield $\left(6.96 \mathrm{t}^{\mathrm{ha}} \mathrm{h}^{-1}\right)$ was obtained from $\mathrm{T}_{2}$ treatment followed by $\mathrm{T}_{1}$ treatment $\left(6.86 \mathrm{t} \cdot \mathrm{ha}^{-1}\right)$. The treatments $T_{1}$ and $T_{2}$ gave 7.19 and $7.20 t^{t} \cdot \mathrm{ha}^{-1}$ grain yield at Dhirasshram village. The $T_{1}$ and $T_{2}$ treatments showed significantly higher grain yields in both the locations compared to other treatments. The $\mathrm{T}_{4}$ treatment gave minimum grain yield of $3.22 \mathrm{t} \cdot \mathrm{ha}^{-1}$ at BRRI farm and $4.37 \mathrm{t} \cdot \mathrm{ha}^{-1}$ at Dhirasshram village.

\subsection{Straw Yield}

The interaction effect of treatment $(\mathrm{T})$ and location $(\mathrm{L})$, and the individual effect of $\mathrm{L}$ on straw yield were not significant $(\mathrm{P}>0.05)$. But the individual effect of $\mathrm{T}$ on straw yield was significant $(\mathrm{P}<0.01)$ (Table 2). The straw yield ranged from 4.13 to $8.17 \mathrm{t} \cdot \mathrm{ha}^{-1}$ at BRRI farm and 4.87 to $7.80 \mathrm{t} \cdot \mathrm{ha}^{-1}$ at Dhirasshram, respectively, irrespective of treatments. In BRRI farm, the treatment $T_{1}\left(7.77 \mathrm{t} \cdot \mathrm{ha}^{-1}\right)$ and $\mathrm{T}_{2}\left(8.17 \mathrm{t} \cdot \mathrm{ha} \mathrm{C}^{-1}\right)$ gave statistically similar straw yield. A similar scenario was also observed in Dhirasshram village. The lowest straw yield was observed in $\mathrm{T}_{4}$ treatment at both the locations.

\subsection{Harvest Index}

The interaction effect and the individual effect of location $(\mathrm{L})$ and treatment $(\mathrm{T})$ were insignificant $(\mathrm{P}>0.05)$ on harvest index. The harvest index ranged from 0.43 to 0.47 at BRRI farm and 0.46 to 0.48 at Dhirasshram village irrespective of treatments (Table 2). 
Table 2. Effect of nitrogen application methods on grain yield, straw yield and HI of BRRI dhan28.

\begin{tabular}{|c|c|c|c|}
\hline Treatment & Grain yield $\left(\mathrm{t} \cdot \mathrm{ha}^{-1}\right)$ & Straw yield $\left(\mathrm{t} \cdot h \mathrm{~h}^{-1}\right)$ & HI (\%) \\
\hline \multicolumn{4}{|c|}{ BRRI farm } \\
\hline $\mathrm{T} 1$ & 6.86 & 7.77 & 0.47 \\
\hline $\mathrm{T} 2$ & 6.96 & 8.17 & 0.46 \\
\hline T3 & 5.18 & 6.27 & 0.45 \\
\hline $\mathrm{T} 4$ & 3.22 & 4.13 & 0.43 \\
\hline \multicolumn{4}{|c|}{ Dhirasshram village } \\
\hline $\mathrm{T} 1$ & 7.19 & 7.68 & 0.48 \\
\hline $\mathrm{T} 2$ & 7.20 & 7.80 & 0.48 \\
\hline $\mathrm{T} 3$ & 5.95 & 6.96 & 0.46 \\
\hline $\mathrm{T} 4$ & 4.37 & 4.87 & 0.47 \\
\hline CV (\%) & 10.4 & 7.8 & 6.7 \\
\hline F-values for $\mathrm{L}$ & ${ }^{*}(0.54)$ & NS & NS \\
\hline F-values for $T$ & ${ }^{* *}(0.76)$ & ${ }^{* * *}(0.64)$ & NS \\
\hline F-values for Lx T & NS & NS & NS \\
\hline
\end{tabular}

*, **, NS significant at the 0.05 and 0.01 probability levels and non-significant, respectively.

\subsection{Plant Height}

The interaction effect of location $(\mathrm{L})$ and treatment $(\mathrm{T})$ on plant height was insignificant $(\mathrm{P}>0.05)$ but the individual effect was significant effect on plant height. In BRRI farm, the highest plant height of $98 \mathrm{~cm}$ was in $\mathrm{T}_{1}$ which was statistically similar to $T_{2}$ treatment. In Dhirasshram, the highest plant height of $100 \mathrm{~cm}$ was observed in $\mathrm{T}_{1}$ than other treatments. The lowest plant height was observed in $\mathrm{T}_{4}$ treatment both in BRRI farm and Dhirasshram village (Table 3 ).

\subsection{Tiller Production at Harvest}

The location $(\mathrm{L})$ and treatment $(\mathrm{T})$ interaction in relation to tiller production was not significant $(\mathrm{P}>0.05)$. The individual effect of $\mathrm{L}$ for tiller number was significant $(\mathrm{P}<0.01)$. The tiller number $\mathrm{m}^{2}$ observed higher in Dhirasshram village compared to that of BRRI farm irrespective of different treatments. The individual effect of $\mathrm{T}$ on tiller production was also significant $(\mathrm{P}<0.01)$ (Table 3$)$. In $\mathrm{T}_{1}$ treatment, tiller production in Dhirasshram showed higher compared to that of BRRI farm. Similar responses to tiller production have been observed in $\mathrm{T}_{2}$, $\mathrm{T}_{3}$ and $\mathrm{T}_{4}$ treatments. The $\mathrm{T}_{4}$ treatment gave the lowest number of tillers in both the locations.

\subsection{Panicle Production}

The location (L) and treatment $(\mathrm{T})$ interaction demonstrated insignificant effect on panicle production per unit area $(\mathrm{P}>0.05)$. But the individual effect of $\mathrm{L}$ and $\mathrm{T}$ was significant $(\mathrm{P}<0.01)$ on panicle production. The panicle production was higher in Dhirasshram compared to that of BRRI farm irrespective of different treatments. The $T_{2}$ treatment gave the higher panicle per unit area followed by $T_{1}$ treatment and the lowest in $T_{4}$ treatment both at BRRI farm and Dhirasshram village (Table 3).

\subsection{Panicle Length}

Interaction effect of location $(\mathrm{L})$ and treatment $(\mathrm{T})$, and the individual effect of $\mathrm{T}$ for panicle length were significant $(P<0.05)$. But the individual effect of $L$ for panicle length was not significant $(P>0.05)$. In BRRI farm, the panicle length varied from $19.72 \mathrm{~cm}$ to $23.06 \mathrm{~cm}$ and in Dhirasshram, it varied from $21.16 \mathrm{~cm}$ to $22.68 \mathrm{~cm}$ among different treatments (Table 3). 
Table 3. Effect of nitrogen application methods on different yield parameters of BRRI dhan28.

\begin{tabular}{|c|c|c|c|c|}
\hline Treatment & Plant height (cm) & Tiller per $\mathrm{m}^{2}$ & Panicle per $\mathrm{m}^{2}$ & Panicle length $(\mathrm{cm})$ \\
\hline \multicolumn{5}{|c|}{ BRRI farm } \\
\hline $\mathrm{T} 1$ & 98 & 327 & 305 & 22.71 \\
\hline $\mathrm{T} 2$ & 95 & 329 & 309 & 22.09 \\
\hline $\mathrm{T} 3$ & 90 & 287 & 265 & 23.06 \\
\hline $\mathrm{T} 4$ & 76 & 207 & 195 & 19.72 \\
\hline \multicolumn{5}{|c|}{ Dhirasshram village } \\
\hline $\mathrm{T} 1$ & 100 & 344 & 323 & 22.68 \\
\hline $\mathrm{T} 2$ & 93 & 356 & 332 & 22.20 \\
\hline Т3 & 96 & 313 & 294 & 22.18 \\
\hline $\mathrm{T} 4$ & 82 & 241 & 222 & 21.16 \\
\hline CV (\%) & 3.3 & 4.9 & 4.8 & 2.4 \\
\hline F-values for $L$ & ${ }^{*}(2.66)$ & ${ }^{* *}(12.95)$ & ${ }^{* *}(11.78)$ & NS \\
\hline F-values for $\mathrm{T}$ & ${ }^{* *}(3.76)$ & ${ }^{* *}(18.31)$ & ${ }^{* *}(16.67)$ & ${ }^{* *}(0.65)$ \\
\hline F-values for $\mathrm{Lx} T$ & NS & NS & NS & ${ }^{*}(0.93)$ \\
\hline
\end{tabular}

*, **, NS significant at the 0.05 and 0.01 probability levels and non-significant, respectively.

\subsection{Grains Panicle ${ }^{-1}$}

ANOVA for filled grain per panicle reflected insignificant interaction effect of location (L) and treatment (T) and of individual effect of $\mathrm{L}$. But the individual effect of $\mathrm{T}$ for filled grain per panicle was significant $(\mathrm{P}<0.01)$. The grain number varied from 79 to 102 at BRRI farm and 88 to 105 at Dhirasshram among the treatments, respectively. The highest number of filled grain was obtained from $T_{1}$ treatment followed by $T_{2}$ treatment both at Gazipur and at Dhirasshram. The lowest number of filled grains was in $\mathrm{T}_{4}$ treatment in both the locations (Table 4).

\subsection{0-Grain Weight}

Interaction effect of location (L) and treatment $(\mathrm{T})$, and the individual effect of $\mathrm{L}$ and $\mathrm{T}$ were insignificant $(\mathrm{P}>$ 0.05) for 1000 grain weight. It ranged from 22.67 to $23.35 \mathrm{~g}$ within BRRI farm and Dhirasshram village (Table 4).

\subsection{Sterility Percentage}

The interaction effect of location (L) and treatment $(\mathrm{T})$, and the individual effect of $\mathrm{T}$ were insignificant $(\mathrm{P}>$ $0.05)$ on sterility percentage. But the individual effect of $L$ on sterility was significant $(P<0.01)$. The sterility ranged from $13.40 \%$ to $15.74 \%$ and $17.15 \%$ to $21.75 \%$ at BRRI farm and Dhirasshram village, respectively (Table 4).

\subsection{Agronomic Use Efficiency (AUE)}

The interaction effect of location (L) and treatment $(\mathrm{T})$ was insignificant $(\mathrm{P}>0.05)$ for agronomic use efficiency (AUE) but the individual effect of $\mathrm{L}$ and $\mathrm{T}$ was significant $(\mathrm{P}<0.01)$. The AUE observed higher at BRRI farm compared to that of Dhirasshram irrespective of different treatments. At BRRI farm, AUE varied from 22 to 42 $\mathrm{kg} \cdot \mathrm{kg}^{-1}$ and 18 to $31 \mathrm{~kg} \cdot \mathrm{kg}^{-1}$ at Dhirasshram village. The highest AUE was obtained from $\mathrm{T}_{2}$ treatment and the lowest was observed in $\mathrm{T}_{4}$ treatment in both the locations (Table 5). In BRRI dhan28, AUE of $\mathrm{N}$ varied from 7.6 to $22.4 \mathrm{~kg} \cdot \mathrm{kg}^{-1}$ and in BRRI dhan29, AUE varied from 5.9 to $30.4 \mathrm{~kg} \cdot \mathrm{kg}^{-1}$ [15]. [7] also reported that AUE was 
Table 4. Effect of nitrogen application methods on different yield parameters of BRRI dhan28.

\begin{tabular}{|c|c|c|c|}
\hline Treatment & Filled grain per panicle & 1000 grain weight (g) & $\%$ sterility \\
\hline \multicolumn{4}{|c|}{ BRRI farm } \\
\hline $\mathrm{T} 1$ & 102 & 22.99 & 15.74 \\
\hline $\mathrm{T} 2$ & 97 & 23.35 & 15.54 \\
\hline $\mathrm{T} 3$ & 92 & 23.09 & 13.90 \\
\hline $\mathrm{T} 4$ & 79 & 23.25 & 13.40 \\
\hline \multicolumn{4}{|c|}{ Dhirasshram village } \\
\hline $\mathrm{T} 1$ & 105 & 22.87 & 19.03 \\
\hline $\mathrm{T} 2$ & 97 & 23.08 & 17.15 \\
\hline $\mathrm{T} 3$ & 93 & 22.67 & 21.75 \\
\hline $\mathrm{T} 4$ & 88 & 22.89 & 18.38 \\
\hline CV (\%) & 8.5 & 2.9 & 18.8 \\
\hline F-values for $\mathrm{L}$ & NS & NS & ${ }^{* *}(1.74)$ \\
\hline F-values for $T$ & ${ }^{* *}(9.96)$ & NS & NS \\
\hline F-values for $\mathrm{Lx} T$ & NS & NS & NS \\
\hline
\end{tabular}

$*^{* * *}$, NS significant at the 0.05 and 0.01 probability levels and non-significant, respectively.

Table 5. Nitrogen use efficiencies of different nitrogen application methods of BRRI dhan28.

\begin{tabular}{|c|c|c|c|c|c|c|}
\hline Treatment & $\begin{array}{l}\text { Agronomic use } \\
\text { efficiency } \\
\left(\mathrm{kg} \cdot \mathrm{kg}^{-1}\right)\end{array}$ & $\begin{array}{c}\text { Physiological } \\
\text { efficiency }\left(\mathrm{kg}^{\circ} \mathrm{kg}^{-1}\right)\end{array}$ & $\begin{array}{l}\text { Agro-physiological } \\
\text { efficiency }\left(\mathrm{kg} \cdot \mathrm{kg}^{-1}\right)\end{array}$ & $\begin{array}{c}\text { Apparent } \\
\text { recovery } \\
\text { efficiency (\%) }\end{array}$ & $\begin{array}{l}\text { Utilization } \\
\text { efficiency } \\
\left(\mathrm{kg} \cdot \mathrm{kg}^{-1}\right)\end{array}$ & $\begin{array}{l}\text { Partial factor } \\
\text { productivity } \\
\left(\mathrm{kg} \cdot \mathrm{kg}^{-1}\right)\end{array}$ \\
\hline \multicolumn{7}{|c|}{ BRRI farm } \\
\hline $\mathrm{T} 1$ & 28 & 102.30 & 51.17 & 59.30 & 60.67 & 57.20 \\
\hline $\mathrm{T} 2$ & 42 & 108.17 & 48.63 & 90.80 & 98.23 & 81.87 \\
\hline $\mathrm{T} 3$ & 22 & 123.97 & 59.30 & 38.90 & 48.23 & 60.93 \\
\hline $\mathrm{T} 4$ & - & - & - & - & - & - \\
\hline \multicolumn{7}{|c|}{ Dhirasshram village } \\
\hline $\mathrm{T} 1$ & 22 & 107.87 & 54.00 & 43.53 & 46.90 & 59.90 \\
\hline $\mathrm{T} 2$ & 31 & 113.47 & 55.73 & 59.70 & 67.77 & 84.73 \\
\hline $\mathrm{T} 3$ & 18 & 117.40 & 50.57 & 36.77 & 43.20 & 70.00 \\
\hline $\mathrm{T} 4$ & - & - & - & - & - & - \\
\hline CV (\%) & 20.4 & 2.8 & 2.3 & 4.2 & 5.0 & 0.8 \\
\hline F-values for $\mathrm{L}$ & ${ }^{*}(5.78)$ & NS & NS & ${ }^{* * *}(2.40)$ & ${ }^{* *}(3.17)$ & ${ }^{* *}(0.59)$ \\
\hline F-values for $\mathrm{T}$ & ${ }^{* *}(7.08)$ & ${ }^{* *}(4.01)$ & $* *(1.56)$ & ${ }^{* *}(2.94)$ & $* *(3.88)$ & ${ }^{* *}(0.72)$ \\
\hline F-values for $\mathrm{Lx} T$ & NS & ${ }^{*}(5.67)$ & ${ }^{* *}(2.21)$ & $* *(4.17)$ & ${ }^{* * *}(5.49)$ & ${ }^{* *}(1.01)$ \\
\hline
\end{tabular}

*, ** NS significant at the 0.05 and 0.01 probability levels and non-significant, respectively.

$23 \mathrm{~kg}$ grain produced per $\mathrm{kg} \mathrm{N}$ applied across $\mathrm{N}$ rates. Agronomic efficiency in low land rice in the tropics is reported to be in the range of 15 to $25 \mathrm{~kg}$ grain produced per $\mathrm{kg}$ of applied $\mathrm{N}$ [16].

\subsection{Physiological Efficiency (PE)}

The location ( $\mathrm{L}$ ) and treatment $(\mathrm{T})$ interaction and the individual effect of $\mathrm{T}$ were significant for physiological 
efficiency (PE). But the individual effect of L was not significant for PE. The PE varied from 102 to $124 \mathrm{~kg} \cdot \mathrm{kg}^{-1}$ at BRRI farm and 108 to $117 \mathrm{~kg} \cdot \mathrm{kg}^{-1}$ at Dhirasshram village irrespective of different treatments (Table 5). At BRRI farm, the treatment $T_{3}$ gave the highest PE compared to all other treatments. A similar scenario was observed at Dhirasshram village. The $T_{1}$ treatment had the lowest PE in both the locations. [15] reported that the PE ranged from 78 to $109 \mathrm{~kg} \cdot \mathrm{kg}^{-1}$ in BRRI dhan28 and 105 to $161 \mathrm{~kg} \cdot \mathrm{kg}^{-1}$ in BRRI dhan29. [7] also reported that the PE was $146 \mathrm{~kg}$ biological yield per unit of $\mathrm{N}$ accumulated in flooded rice cultivar Metica 1.

\subsection{Agro-Physiological Efficiency (APE)}

The location (L) and treatment (T) interaction and the individual effect of $\mathrm{T}$ for agro-physiological efficiency (APE) were significant $(P<0.01)$. But the individual effect of $L$ was not significant $(P>0.05)$ for APE. At BRRI farm, the $T_{3}$ treatment had the highest APE compared to all other treatments (Table 5). The $T_{1}$ treatment gave significantly higher APE compared to $T_{2}$ treatment and the lowest APE was observed in $T_{2}$ treatment. At Dhirasshram village, the $T_{2}$ treatment had the highest APE followed by $T_{1}$ treatment and the lowest APE was obtained from $\mathrm{T}_{3}$ treatment. [15] reported that APE varied from 50 to $71 \mathrm{~kg} \cdot \mathrm{kg}^{-1}$ in BRRI dhan28 and 20 to 62 $\mathrm{kg} \cdot \mathrm{kg}^{-1}$ in BRRI dhan29. [7] also reported that APE was $63 \mathrm{~kg}$ grain produced per $\mathrm{kg}$ of $\mathrm{N}$ accumulated in the grain and straw across $\mathrm{N}$ rates. [17] reported that an APE of about $64 \mathrm{~kg}$ grain per $\mathrm{kg}$ of $\mathrm{N}$ uptake in 20 lowland rice genotypes.

\subsection{Apparent Recovery Efficiency (ARE)}

The interaction of location $(\mathrm{L})$ and treatment $(\mathrm{T})$ for apparent recovery efficiency (ARE) demonstrated significant effect $(\mathrm{P}<0.01)$, however, both $\mathrm{L}$ and $\mathrm{T}$ individually produced significant effect on the ARE $(\mathrm{P}<0.01)$. At BRRI farm, the $T_{2}$ treatment gave significantly higher ARE compared to all other treatments. The $T_{1}$ treatment gave significantly higher ARE in comparison to $T_{3}$ treatment (Table 5). At Dhirasshram village, the $T_{2}$ treatment had the highest ARE compared to all other treatments. The ARE for $T_{1}$ and $T_{2}$ treatments at BRRI farm were significantly greater compared to those of Dhirasshram village. [15] reported that ARE of $\mathrm{N}$ varied from $24 \%$ to $41 \%$ in BRRI dhan28 and BRRI dhan38 to $54 \%$ in BRRI dhan29. For low land rice in the tropics ARE is $30 \%$ to $50 \%$ of applied $\mathrm{N}$ depending on season, yield level, the rate and timing of $\mathrm{N}$ application [16]. [7] also reported that ARE was 39\% across $\mathrm{N}$ rates in flooded rice cultivar Metica 1. Studies conducted in the southern USA on the influence of different $\mathrm{N}$ application timings and $\mathrm{N}$ management strategies on $\mathrm{N}$ use efficiency in rice showed recovery at maturity of $17 \%$ to $61 \%$ of the applied $\mathrm{N}$ [18] [19]. [17] reported an $\mathrm{N}$ recovery efficiency of $37 \%$ in 20 low land rice genotypes. Furthermore, nitrogen recovery efficiency for lowland rice is less than $50 \%$ [20]. The low $\mathrm{N}$ recovery efficiency in lowland rice may be related to $\mathrm{N}$ loses from soil via nitrification-de nitrification, $\mathrm{NH}_{3}$ volatilization or leaching.

\subsection{Utilization Efficiency (UE)}

The individual effect of location $(\mathrm{L})$ and treatment $(\mathrm{T})$, and the interaction effect of $\mathrm{L}$ and $\mathrm{T}$ for utilization efficiency (UE) were significant $(\mathrm{P}<0.01)$. Among the treatments, the $\mathrm{T}_{2}$ treatment gave significantly greater UE both at BRRI farm and Dhirasshram village (Table 5). In between the two locations the UE was higher at BRRI farm compared to that of Dhirasshram village irrespective of treatments. The lowest UE was obtained from $\mathrm{T}_{4}$ treatment in both the locations. [15] reported that UE varied from 19 to $39 \mathrm{~kg} \cdot \mathrm{kg}^{-1}$ in BRRI dhan28 and 31 to 75 $\mathrm{kg} \cdot \mathrm{kg}^{-1}$ in BRRI dhan29, respectively. A flooded rice variety, Metica 1, from South America showed an average UE of $58 \mathrm{~kg} \cdot \mathrm{kg}^{-1}$ across $\mathrm{N}$ rates [7]. [16] also reported that the efficiency of utilization for grain production in the tropics is about $50 \mathrm{~kg}$ grain per $\mathrm{kg} \mathrm{N}$ absorbed and this efficiency appears to be almost constant regardless of the rice yields achieved.

\subsection{Partial Factor Productivity (PFP)}

The location ( $\mathrm{L}$ ) and treatment $(\mathrm{T})$ interaction, and the individual effect of $(\mathrm{L})$ and $(\mathrm{T})$ for partial factor productivity (PFP) were significant $(\mathrm{P}<0.01)$. The treatment $\mathrm{T}_{2}$ gave the highest PFP compared to other treatments both at BRRI farm and Dhirasshram village (Table 5). Irrespective of treatments, the PFP at Dhirasshram village was greater compared to that of BRRI farm. [15] reported that PFP of $\mathrm{N}$ varied from 18 to $83 \mathrm{~kg} \cdot \mathrm{kg}^{-1} \mathrm{in}$ BRRI dhan28 and 22 to $91 \mathrm{~kg} \cdot \mathrm{kg}^{-1}$ in BRRI dhan29. 


\subsection{Economic Performance Evaluation}

Prilled urea application by applicator (PUA) can save approximately TK. 1800 per hectare compared to existing recommended $\mathrm{N}$ fertilizer management system. At present the total boro rice cultivated area is about 47.91 lakh hectare (ha) of which high yielding varieties (HYV) and hybrid rice together occupies 47.35 lakh ha in Bangladesh [21]. Three splits nitrogen management were followed mostly in these (47.35 lakh ha) areas. Based on this finding if the $\mathrm{N}$ management of these areas could be done by applicator instead of traditional method, the country could save TK. 852.3 crore i.e. 106.54 million US \$ by using about 30\% less $\mathrm{N}$ fertilizer in boro season.

\section{Conclusion}

Prilled urea applicator is a new technology in rice production in Bangladesh. It gave the highest agronomic use efficiency, apparent recovery efficiency, utilization efficiency and partial factor productivity among the different $\mathrm{N}$ management options without scarifying grain yield. Based on the findings, it can be concluded that prilled urea applicator could save about 30\% urea effectively and our country could save about 107 million US \$ only in boro season discarding $\mathrm{N}$ fertilizer cost. It has opened the possibilities for substantial savings from fertilizer and for rice yield increases in Asia and rice producers may be suggested to apply urea using applicator for their economic benefit.

\section{Acknowledgements}

The first author acknowledges the FMPHT division, Bangladesh Rice Research Institute, Bangladesh, for providing technical and financial support for the study.

\section{References}

[1] Mamun, M.A.A., Rana, M.M., Mridha, A.J. and Rahman, M.A. (2013) Determination of Seedling Age for Rice Transplanter. Scientific Journal of Crop Science, 2, 116-124.

[2] Fageria, N.K., Stalon, N.A. and Baligar, V.C. (2003) Nutrient Management for Improving Lowland Rice Productivity and Sustainability. Advances in Agronomy, 80, 63-152. http://dx.doi.org/10.1016/S0065-2113(03)80003-2

[3] Clayton, S. (2010) 50-Years of Rice Science for a Better World and It's Just the Start! Rice. Today, IRRI.

[4] Fageria, N.K., Santos, A.B. and Cutrim, V.A. (2008) Dry Matter and Yield of Lowland Rice Genotypes as Influence by Nitrogen Fertilization. Journal of Plant Nutrition, 31, 788-795. http://dx.doi.org/10.1080/01904160801928471

[5] Saleque, M.A., Abedin, M.J., Bhuiyan, N.I., Zaman, S.K. and Panaullah, G.M. (2004) Long-Term Effects of Inorganic and Organic Fertilizer Sources on Yield and Nutrient Accumulation of Lowland Rice. Field Crops Research, 86, 5365. http://dx.doi.org/10.1016/S0378-4290(03)00119-9

[6] Chaturvedi, I. (2005) Effect of Nitrogen Fertilizers on Growth, Yield and Quality of Hybrid Rice. Journal of Central European Agriculture, 6, 611-618.

[7] Fageria, N.K. and Baligar, V.C. (2001) Lowland Rice Response to Nitrogen Fertilization. Communications in Soil Science and Plant Analysis, 32, 1405-1429. http://dx.doi.org/10.1081/CSS-100104202

[8] Khan, A.U., Kiamco, L.C., Tiangco, V.M., Diestro, M.S. and Bautista, E.U. (1984) Applicators for Improved Fertilizer Use Efficiencies in Wetland Paddies. Philippine Journal of Crop Science, 9, 206-216.

[9] Craswell, E.T. and Vlek, P.L.G. (1979) Fate of Fertilizer Nitrogen Applied to Wetland Rice. In: Nitrogen and Rice, IRRI, Los Baños, 175-192.

[10] Prasad, R. and Datta, S.K.D. (1979) Increasing Efficiency of Fertilizer Nitrogen in Wetland Rice. In: Nitrogen and Rice, IRRI, Los Baños, 465-484.

[11] Mohanty, S.K., Singh, U., Balasubramanian, V. and Jha, K.P. (1999) Nitrogen Deep-Placement Technologies for Productivity, Profitability and Environmental Quality of Rainfed Lowland Rice Systems. Nutrient Cycling in Agroecosystems, 53, 43-57. http://dx.doi.org/10.1023/A:1009731922431

[12] Yoshida, S., Forno, D.A., Cock, J.H. and Gomez, K.A. (1976) Laboratory Manual for Physiological Studies of Rice. 3rd Edition, International Rice Research Institute, Manila.

[13] Fageria, N.K., Santos, A.B. and Baligar, V.C. (1997) Phosphorus Soil Test Calibration for Lowland Rice on an Inceptisol. Agronomy Journal, 89, 737-742. http://dx.doi.org/10.2134/agronj1997.00021962008900050005x

[14] Gomez, K.A. and Gomez, A.A. (1984) Statistical Procedure for Agricultural Research. 2nd Edition, John Willey and Sons, Singapore City, 28-192. 
[15] Khatun, A. (2014) Effect of Nitrogen from Organic and Inorganic Sources on Plant Nutrient Composition, Yield and Seed Quality of Boro Rice. Ph.D. Dissertation, Department of Agronomy, Bangladesh Agricultural University, Mymensingh.

[16] Yoshida, S. (1981) Fundamentals of Rice Crop Science. IRRI, Los Banos, 235-269.

[17] Singh, U., Ladha, J.K., Castillo, E.G., Punjalan, G., Tirol-Padre, A. and Duqueza, M. (1998) Genotypic Variation in Nitrogen Use Efficiency in Medium and Long Duration Rice. Field Crops Research, 58, 35-53. http://dx.doi.org/10.1016/S0378-4290(98)00084-7

[18] Norman, R.J., Wells, B.R. and Moldenhauer, K.A.K. (1989) Effect of Application Method and Dicyandiamide on Urea-Nitrogen-15 Recovery in Rice. Soil Science Society of America Journal, 53, 1269-1274. http://dx.doi.org/10.2136/sssaj1989.03615995005300040046x

[19] Westcott, M.P., Brandon, D.M., Lindau, C.W. and Patrick Jr., W.H. (1986) Effects of Seeding Method and Time of Fertilization on Urea-Nitrogen-15 Recovery in Rice. Agronomy Journal, 78, 474-478. http://dx.doi.org/10.2134/agronj1986.00021962007800030016x

[20] Fageria, N.K. and Baligar, V.C. (2005) Enhancing Nitrogen Use Efficiency in Crop Plants. Advances in Agronomy, 88, 97-185. http://dx.doi.org/10.1016/S0065-2113(05)88004-6

[21] BBS (2014) Estimates of Boro Rice (Husked). Bangladesh Bureau of Statistics. Government of People’s Republic of Bangladesh. http://www.bbs.gov.bd 